\title{
Incidence and Severity of Early Blight of Tomato in Peshawar, Mardan and Malakand Divisions and Variability Amongst the Isolates of Alternaria solani Jones and Mart
}

\author{
Habibullah Safi", Shaukat Hussain, Muhammad Shahid and Muhammad Nazir
}

Department of Plant Pathology, The University of Agriculture, Peshawar, Pakistan

*Corresponding author: habibsafi75@gmail.com (ORCID ID: 0000-0003-3694-5498)

Paper No. 834

Received: $10-01-2020$

Revised: 15-04-2020

Accepted: 24-05-2020

\begin{abstract}
An extensive survey for incidence and severity of early blight of tomato was conducted in Peshawar, Mardan and Malakand Divisions of Khyber Pakhtunkhwa Province after flower formation and fruit setting during 2012. The survey points were 3-5 km apart from one another. At each location fields were assessed in " $X$ " shaped pattern. A high incidence of the disease (40\%) was recorded at Jahangira District Nowshera, whereas the lowest disease incidence $4.9 \%$ was recorded at Taru Jaba in Peshawar Division. In Mardan Division high incidence of the disease was recorded at Galadher 38.6\% in District Mardan whereas the lowest at Jalbai 3.3\% in Distrct Swabi. A similar disease incidence was found at Osaki and Nasafa locations in District Dir (L). Conversely, high incidence of the disease was recorded in Ghalegai (20\%) in District Swat Malakand Division. In terms of the disease severity Jahangira (8.66\%) in District Nowshera was the most severely infested area closely followed by Basher Mian Kaly (7.98\%) and Shabqadar (7.66\%). In general, isolates collected from Peshawar and Mardan Divisions were more virulent than those collected from Malakand Division by exhibiting rapid growth on PDA medium as well as producing high number of spore's $\mathrm{ml}^{-1}$. Isolates collected from Shabqadar measured $33 \mathrm{~mm}$ in diameter with 28000 spore $\mathrm{ml}^{-1}$ and proved virulent by producing high disease severity (27.6\%). Conversely, isolates collected from Talash (Malakand Division) showed minimum growth $(22 \mathrm{~mm})$ with least number of spores $\mathrm{ml}^{-1}$ and disease severity of $16.44 \%$ only. Regression analysis showed a simple linear relationship between growth parameters and virulence and as expected virulence increased with increase in colony diameter and spore concentration of the pathogen. Results are indicative of segregation in population structure of the pathogen and may correlate with the different environmental conditions prevalent in the central part of the province

Highlights

(0 Early blight is a destructive disease of tomato in humid condition
\end{abstract}

Keywords: Early blight, Tomato, Incidence, Severity and Variability in A. solani isolates

Tomato (Solonum esculentum L.), a member of family solonaceae, is a rich source of vitamin A, B, C and minerals (Taylor 1987). Its fruit is used both fresh as well as processed. It is also a model plant in research to determine various types of abiotic stress including temperature, light, salt and droughts. In fact it ranks first as a processed crop and next to potato in world acreage among vegetables. The area under cultivation of tomato in Pakistan during 2011-12 reached over 52.3 thousand hectares with total production of 529.9 thousand tones and a yield of $10131.92 \mathrm{~kg}$ per hectare (Anonymous, 2011-12). Khyber Pakhtunkhwa with a total production of 113.2 thousand tonnes, ranks next to Baluchistan and Sindh in terms of production. Ironically, the yield of tomatoes per hectare in Pakistan is far below than global averages of 36 tones/ha. Various factors are responsible for this low yield of the crop which include diseases, insects and weeds. 
Tomatoes are vulnerable to infection by bacterial, fungal and viral diseases (Gomaa 2001; Abdel-Sayed 2006; Abada et al. 2008), in addition to physiological disorders and nematode infections. However, early blight, caused by Alternaria solani (Ellis and Martin) Jones and Grout, is the most threatening disease (ElAbyad et al. 1993; Gomaa 2001; Abdel-Sayed 2006; Abada et al., 2008), which causes great reduction in fruit yield both qualitatively and quantatively. Yield losses up to $79 \%$ were reported from many countries like Canada, India, USA, and Nigeria (Sherf and MacNab 1986; Gwary and Nahunnaro 1998).

Early blight is manifested by small, black, necrotic lesions that are usually visible on the older leaves and spread upward as the plants mature. As lesions enlarge, they commonly show concentric rings and are often surrounded by a yellowing zone. Besides tomato, the same type of symptoms are observed on other hosts also (Chaearani et al. 2007). In a severe epidemic, the pathogen can enhance complete premature defoliation, which weakens the plants and predisposes the fruit to injury from sunscald. In seedlings large, dark and sunken lesions may appear on the stems at the ground level, causing partial girdling known as collar rot (Sherf and MacNab 1986). However, plants are more susceptible to infection during the fruit set (Cerkauskas 2005; Momel and Pemezny 2006). Heavily infected fruits in susceptible genotypes often drop prematurity. Additionally, the calyx and blossom may also become infected (Pandey et al. 2003; Chaearani and Voorrips 2006).

Alternaria spp. have no known sexual stage forming overwintering spores called chlamydospore. It can also survive as mycelium or conidia on decaying plant debris (Patterson 1991). Survival on volunteer plants as well as weed hosts for a considerable period of time, or as latent infection in seeds has also been reported (Rotem 2004). Other hosts of A. solani, besides tomato, include potato, eggplant and some solonacious and non solonacious weeds (Pscheidt 1985). The primary inoculum releases abundant conidia in spring, which are then splashed or wind dispersed to the lower leaves of the nearby plants, where they germinate and cause infection (Rotem 2004). The pathogen has typical dry-dispersed spores, having slightly rough surfaces with darkcolored walls and are produced away from the host surface on aerial conidiophores (Fitt et al. 1989).
Despite its importance and the losses it causes, no systematic work has been taken up in the past on this disease. Present studies were, therefore, planned to conduct a comprehensive survey of Peshawar, Mardan and Malakand Divisions to get first-hand information on the prevalence and the severity of this disease in the tomato growing belt.

The variability in the pathogen population has an adverse effect on the management strategies with a great emphasis on the evaluation of the host resistance and fungicidal sensitivity (McDonald and Linde 2002; Milgroom and Peever 2003). Therefore, pathogen variability studies are expected to determine the genetic profile of the pathogen which will form a baseline for the breeders to conduct varietal screening under variable pathogen population.

The overall objectives of the present study therefore were:

1. To record incidence and severity of the disease in Peshawar, Mardan and Malakand Divisions.

2. To determine variability amongst the isolates of Alternaria solani by using phenotypic markers.

\section{MATERIALS AND METHODS}

\section{Incidence and severity of early blight}

An extensive survey was conducted in various tomato growing areas of Khyber Pakhtunkhwa (KPK) to determine incidence and severity of the disease. Survey was done after flower formation and fruit setting since plants near maturity are more prone to infection. The survey points were 3-5 kilometer apart from each other. At each location, fields were assessed in " $X$ " shaped pattern where 30 plants were selected randomly. The incidence of the disease was determined by using the following equation.

Percent disease incidence $=$

$$
\frac{\text { Number of plants infected }}{\text { No. of plants examined }} \times 100
$$

Severity of the disease in each field was assessed by using 0-5 scale devised by Mayee and Datar (1986) where 0 means no visible symptoms on foliage / 
fruits while a rating of 5 would suggest more than $70 \%$ infection. Percent Disease Index (PDI) was then worked out by using equation as suggested by Wheeler (1969).

Percent Disease Index $(\mathrm{PDI})=$

$$
\begin{gathered}
\frac{\text { Sum of individual ratings }}{\text { No. of plants examined } \times} \times 100 \\
\text { Maximum disease scale }
\end{gathered}
$$

Following incidence and severity determination, samples were placed separately in paper bags, appropriately labeled and immediately shipped to the Department of Plant Pathology, University of Agriculture, Peshawar where they were stored at $4^{\circ} \mathrm{C}$ until further processing.

Isolation: Diseased specimen were excised into $1 \mathrm{~cm}^{2}$ pieces using sterilized razor and dipped in $2 \% \mathrm{NaOCl}$ for $2 \mathrm{~min}$. Excessive disinfectant was removed by rinsing with sterilized distilled water thrice followed by drying on sterilized filter paper and plating 3 or 4 pieces aseptically in Petri plates containing PDA to be later incubated at $25 \pm 2^{\circ} \mathrm{C}$ for one week or until colony developed. Cultures were purified by excising peripheral hyphal tips of the growing culture and placing them aseptically on PDA. The plates were sealed and incubated at $25 \pm 2^{\circ} \mathrm{C}$ and the pathogen was identified by mycological keys of Simmons (2007) and maintained at $4^{\circ} \mathrm{C}$ for subsequent studies.

Table 1: Disease rating scale used to calculate disease severity of early blight of tomato

(Mayee and Datar, 1986).

\begin{tabular}{ll}
\hline Scale & Scale description \\
\hline 0 & Healthy, No visibility of symptom on leaf. \\
1 & $\begin{array}{l}0-5 \% \text { leaf area infected but not present on petiole } \\
\text { and branches. }\end{array}$ \\
2 & $\begin{array}{l}6-20 \% \text { leaf area infected and covered by spot, } \\
\text { some spots on petiole. }\end{array}$ \\
3 & $\begin{array}{l}21-40 \% \text { leaf area infected and covered by spot, } \\
\text { spots also seen on petiole, branches. }\end{array}$ \\
4 & $\begin{array}{l}41-70 \% \text { leaf area infected and covered by spot, } \\
\text { spots also seen on petiole branches stem. }\end{array}$ \\
5 & $>71 \%$ leaf area infected and covered by spot, spots \\
& also seen on petiole, branch, stem, fruits.
\end{tabular}

Population variability studies: Isolates collected during the survey were analyzed for variation based on phenotypic markers including growth on culture media as well as their aggressiveness. Data were then pooled to assess overall variability of the pathogen isolates.

Assessment of variation through cultural characteristics: Pathogen isolates collected from various regions during the previous survey and maintained on PDA were assessed for variability based on radial growth and number of spores $\mathrm{ml}^{-1}$. Isolates were grown individually on PDA under aseptic conditions. The plates were sealed with parafilm and incubated on $25^{\circ} \mathrm{C}$ for one week. Colony diameter was measured by taking the growth along the two perpendicular lines and then taking the means of two measurements. Likewise, number of spores $\mathrm{ml}^{-1}$ was calculated with the help of a haemocytometer. The data were log transformed to avoid large computations. The treatments were arranged in a completely randomized design with three replications.

Assessment of virulence: A nursery of tomato cultivar, Jumbo, was raised in earthen pots containing equal amounts of sterilized sand, clay and FYM. These pots were watered regularly and covered with a white polyethylene plastic sheet to allow rapid germination. After true leaf emergence, seedlings were then individually transplanted into the separate pots. The experiment was laid as completely randomized design with three replications. Prior to inoculation, the plants were kept in a humidifier to facilitate infection. Inoculum of each isolate @ $1 \times 10^{4}$ spores $\mathrm{ml}^{-1}$ was prepared and sprayed on the leaves during the evening hours to maintain humid environment. Data were recorded one week after inoculation on disease severity according to the scale described by Ghosh et al. (2009) where $0=$ no visible infection, $1=0-10 \%$ leaf area are infected, $2=10-20 \%, 3=20-30 \%, 4=30-40$, $5=40-50 \%, 6=50-60 \%, 7=60-70 \%, 8=70-80 \%$ and $9=80-90 \%$ of leaf damaged. Regression analysis was used to predict the relationship between cultural characteristics such as colony diameter and virulence. A similar relationship was also worked out for spore concentration and virulence.

\section{RESULTS AND DISCUSSION}

\section{Incidence and severity of early blight of tomato in Peshawar, Mardan and Malakand Divisions}

Various tomato growing areas of Peshawar and 
Mardan Divisions were surveyed during spring 2012 growing season while those of Malkand Division in autumn 2012 to record incidence and severity of early blight. A comparatively high incidence and severity were noticed in Peshawar and Mardan than Malakand Division in below table. In Peshawar Division the district wise disease incidence ranged between $14.4-26.6 \%$. The highest disease incidence was recorded in District Nowshera where some individual locations such as Jahangira showed an incidence as high as $40 \%$. Interestingly, the lowest disease incidence was also recorded in District Nowshera where $4.9 \%$ disease incidence was found at Taru Jaba area in Peshawar Division. Similarly, in Mardan Division the district wise incidence of the diseases ranged between 10.5$24.9 \%$. The highest disease incidence was recorded in District Mardan in which an individual location such as Galadher showed an incidence as high as $38.6 \%$ while the lowest incidence was recorded in Jalabi 3.3\% District Swabi. Conversely, in Malakand Division the district wise disease incidence ranged between $5.5-18.2 \%$. The highest disease incidence was recorded in District Swat where an individual location such as Ghalegai showed an incidence as high as $20 \%$. On the other hand, the lowest disease incidence was recorded in District Dir (L) where $3.3 \%$ disease incidence was found at Osaki and Nasafa.

In Peshawar Division, the district wise disease severity ranged between $4-6.3 \%$. The highest disease severity was recorded in District Charsada followed by District Nowshera where some individual locations such as Jahangira showed a severity as high as $8.6 \%$. Interestingly, the lowest disease severity was also recorded in District Nowshera where $0.9 \%$ disease severity was found at Taru Jaba. Similarly, in Mardan Division district wise severity of the disease ranged between $3-5.5 \%$. The highest disease severity was recorded in Distract Mardan but unfortunately in District Swabi an individual location such as Chota Lahore showed highest severity $6.6 \%$ and the lowest was also found at Jalabi $0.6 \%$. In Malakand Division,on the other hand, the district wise disease severity ranged between 0.9-4.4\%, recorded in District Swat where some individual locations such as Barikot showed a severity as high 5.3\%. Conversely, the lowest disease severity was recorded in District Dir (L) where $0.6 \%$ disease severity was found at Osaki and Nasafa.

Table 2: Incidence and severity of the early blight of tomato in Peshawar, Mardan and Malakand Divisions

\begin{tabular}{|c|c|c|c|c|c|c|}
\hline \multirow[b]{2}{*}{ Division } & \multirow[b]{2}{*}{ District } & \multirow[b]{2}{*}{ Location } & \multirow[b]{2}{*}{$\begin{array}{l}\text { Percent disease } \\
\text { Incidence }\end{array}$} & \multirow[b]{2}{*}{$\begin{array}{l}\text { Percent disease } \\
\text { severity }\end{array}$} & \multicolumn{2}{|c|}{ Grand Mean } \\
\hline & & & & & $\begin{array}{l}\text { Percent disease } \\
\text { incidence }\end{array}$ & $\begin{array}{l}\text { Percent disease } \\
\text { severity }\end{array}$ \\
\hline \multirow{9}{*}{ Peshawar } & \multirow{3}{*}{ Peshawar } & Baba Khan Kaly & 19.9 & 3.8 & \multirow{3}{*}{14.4} & \multirow{3}{*}{4.2} \\
\hline & & Malakandher & 6.6 & 4.2 & & \\
\hline & & Jhagra & 16.6 & 5.3 & & \\
\hline & \multirow{3}{*}{ Nowshera } & Taru Jaba & 4.9 & 0.9 & \multirow{3}{*}{19.9} & \multirow{3}{*}{4} \\
\hline & & Jhnagaira & 40 & 8.6 & & \\
\hline & & Azakhel Bala & 13.3 & 2.7 & & \\
\hline & \multirow{3}{*}{ Charsada } & Shabqadar & 28.3 & 7.6 & \multirow{3}{*}{26.6} & \multirow{3}{*}{6.3} \\
\hline & & Harichand & 15 & 3.3 & & \\
\hline & & Basher Mian Kaly & 36.6 & 7.9 & & \\
\hline \multirow{6}{*}{ Mardan } & \multirow{3}{*}{ Mardan } & Muqeem Choak & 19.9 & 4.6 & \multirow{3}{*}{24.9} & \multirow{3}{*}{5.5} \\
\hline & & Shagonaqi & 16.6 & 5 & & \\
\hline & & Galadher & 38.6 & 6 & & \\
\hline & \multirow{3}{*}{ Swabi } & Chota Lahore & 18.3 & 6.6 & \multirow{3}{*}{10.5} & \multirow{3}{*}{3} \\
\hline & & Jalabi & 3.3 & 0.6 & & \\
\hline & & Toor Dher & 10 & 2 & & \\
\hline \multirow{6}{*}{ Malkand } & \multirow{3}{*}{ Swat } & Barikot & 16.3 & 5.3 & \multirow{3}{*}{18.2} & \multirow{3}{*}{4.4} \\
\hline & & Ghalegai & 20 & 4 & & \\
\hline & & Minyar & 18.3 & 3.9 & & \\
\hline & \multirow{3}{*}{$\operatorname{Dir}(\mathrm{L})$} & Talash & 8.3 & 1.6 & \multirow{3}{*}{5} & \multirow{3}{*}{0.9} \\
\hline & & Osaki & 3.3 & 0.6 & & \\
\hline & & Nasafa & 3.3 & 0.6 & & \\
\hline
\end{tabular}




\section{Variability of Alternaria solan}

Radial growth: Isolates collected from different tomato growing areas were significantly $(\mathrm{P} \leq 0.05)$ different on the basis of radial growth when tested on PDA medium following one week of incubation at $25^{\circ} \mathrm{C}$ in table 3 . In general, isolates collected from Peshawar and Mardan Divisions exhibited faster radial growth on PDA than those collected from Malakand Division. Isolate collected from Shabqadar $(33.0 \mathrm{~mm})$ exhibited the most rapid growth (Fig. 1 and 2) followed by those collected from Aza Khel and Jhagra $(30.3 \mathrm{~mm})$. However, they were statistically at par with one another. The lowest growth was recorded for the isolate collected from Talash which was $22 \mathrm{~mm}$.

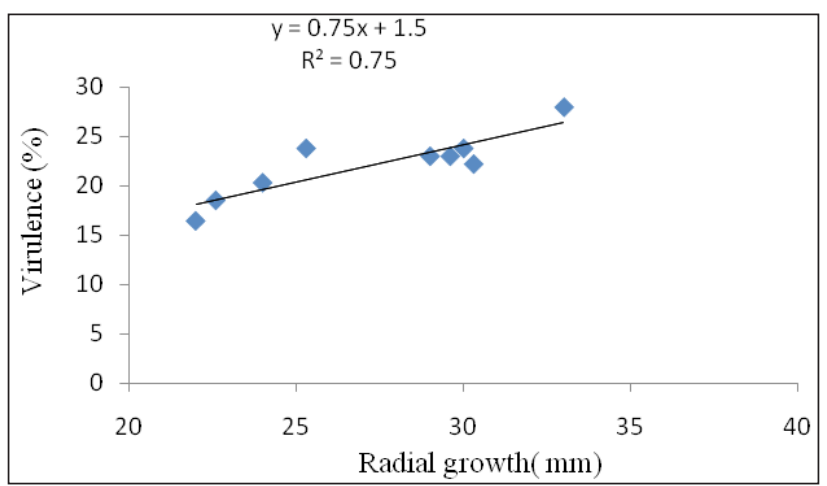

Fig. 1: Relationship between radial growth and virulence of different isolates of A.solani collected from Peshawar, Mardan and Malkand Divisions

Number of spores $\mathrm{ml}^{-1}$ : As expected on the basis of radial growth data, there was a clear cut demarcation between isolates collected from
(Peshawar and Mardan) and Malakand Divisions in terms of their spore concentration. In general, those collected from Peshawar and Mardan Division had significantly more spores $\mathrm{ml}^{-1}$ when compared with those collected from Malakand Division. It was interesting to note that all isolates collected from Peshawar and Mardan Division were statistically at par. The least number of the spores were produced by the isolate collected from Nasafa, Malakand Division (15000).

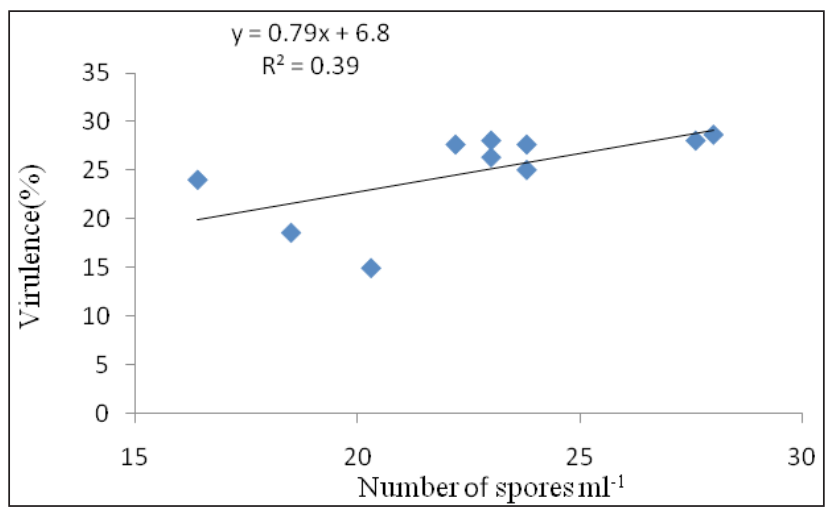

Fig. 2: Relationship between spore concentration and virulence of different isolates of A.solani collected from Peshawar, Mardan and Malkand Divisions

Virulence: Isolates of $A$. solani differed significantly $(\mathrm{P} \leq 0.05)$ in terms of virulence when tested in planta on tomato leaves in screen house. Generally, severity of the isolates ranged from $16.4-27.6 \%$ in terms of diseases development. Isolate collected from Toor Dehr was the most virulent (27.7\%) closely followed by the one collected from Shabqadar. However, the two isolates were statistically non-significant.

Table 3: Radial growth and spore concentration of $A$. solani isolates (cultured from various locations) as assessed on PDA and their virulence recorded on cv. Jumbo

\begin{tabular}{lllll}
\hline District & Location & Radial growth $\mathbf{( m m )}$ & Number of spores $\mathbf{~ m l}^{-\mathbf{1}} \mathbf{( 0 0 0 )}$ & Virulence $\mathbf{( \% )}$ \\
\hline Charsada & Shabqadar & $33.0 \mathrm{a}$ & $28.6 \mathrm{a}$ & $27.0 \mathrm{a}$ \\
Peshwar & Jagra & $30.3 \mathrm{ab}$ & $27.6 \mathrm{a}$ & $22.2 \mathrm{abc}$ \\
Nowshera & Azakhel Bala & $30.3 \mathrm{ab}$ & $27.6 \mathrm{a}$ & $23.8 \mathrm{ab}$ \\
Charsada & Harichand & $29.6 \mathrm{abc}$ & $28.0 \mathrm{a}$ & $23.0 \mathrm{ab}$ \\
Nowshera & Jhangira & $29.0 \mathrm{abc}$ & $26.3 \mathrm{a}$ & $23.0 \mathrm{ab}$ \\
Swabi & Toor Dehr & $27.6 \mathrm{abcd}$ & $28.0 \mathrm{a}$ & $27.6 \mathrm{a}$ \\
Mardan & MuqeemChowk & $25.3 \mathrm{bcde}$ & $25.0 \mathrm{ab}$ & $23.8 \mathrm{ab}$ \\
Dir (L) & Nasafa & $24.0 \mathrm{cde}$ & $15.0 \mathrm{c}$ & $20.3 \mathrm{bc}$ \\
Swat & Barikot & $22.6 \mathrm{de}$ & $18.6 \mathrm{bc}$ & $18.5 \mathrm{bc}$ \\
Dir (L) & Talash & $22 \mathrm{e}$ & $24.0 \mathrm{ab}$ & $16.4 \mathrm{c}$ \\
\hline
\end{tabular}

$L S D$ value for radial growth $=5.77 ; L S D$ value for the number of spores $m l^{-1}=6.56 ; L S D$ value for virulence $=6.564$. 
The lowest values were obtained from the isolate collected from Talash (16.4\%) Malakand Division.

Regression analysis of radial growth and virulence of the isolates revealed that there was a simple linear relationship between the two variables. Moreover, the regression line showed a good fit to the data $\left(\mathrm{R}^{2}=0.76\right)$ implicating that virulence increased with increase in the colony diameter of the pathogen. The regression equation was $Y=0.75 x+1.56$ which indicates that with a unit (1\%) increase in the radial growth, the virulence of the pathogen increased by $0.75 \%$. The regression equation may be extrapolated for future predication.

Similarly, regression analysis of spore concentration and virulence of the isolates revealed that there was a simple linear relationship between the two variables. However, it is pertinent to mention here that the regression line showed a poor fit to the data $\left(R^{2}=0.40\right)$. The regression equation $Y=0.79 x+$ 6.86 indicates that a unit $(1 \%)$ increase in number of spores $\mathrm{ml}^{-1}$ increasesthe virulence of the pathogen by $0.79 \%$.

\section{Discussion}

The present studies encompassed a comprehensive survey of various regions of Khyber Pakhtunkhwa (KPK) including Peshawar, Mardan and Malakand Divisions. Comparatively low disease incidence and severity was witnessed in Malakand than in Peshawar and Mardan Divisions. This can be due to various factors including low humidity in fields with good irrigation system of tube wells, use of hybrid seeds (moderately resistant) followed by the application of routine fungicides as well as their rotation with cereals. Generally these fields are cultivated for tomato followed by cereal or foliage crops which are not host to Alternaria solani, and thus did not allow overwintering of the pathogen. The results are in agreement with those of Harrison et al. (1965) who opined that early blight can be reduced to significant levels by rotation with the non-host crops. Alternatively, in Mardan, Peshawar, Charsada, Swabi and Nowshara areas of the Peshawar and Mardan Divisionsa field is cultivated continuously with same solonacious crops such as brinjal, pepper and potato. Moreover, other solonacious crops were also present nearby throughout the growing season which might become a potential source of inoculum for current or next growing tomato crops and may result in enhanced disease incidence and severity (Pelletier 1988; Shuman 1995). Steinberg and Fry (1990) reported that a field consecutively cropped with tomato and potato brings earlier infection than a field cropped with alternate crops like maize, grains etc. The above results are also in line with Rotem (2004) who reported that six month rotation with crops other than solonacious plants may reduce the inoculum to threshold level.

It was further noticed during the surveythat there was no alternative host of $A$. solani in the form of weeds present in Khyber Pakhtunkhwa. These weed generally compete for nutrients and space. However, mostly in tomato fields weeds are rouged out after transplanting of tomato in the field. The practice is repeated for 20 to 30 days after transplantation. Further, Solonum nigrum, present in tomato seeds as concomitant contamination should be cleaned up before planting. Beside others nightshade plants, field bind weed (Convolous arvensis) was prominent both in Peshawar, Mardan and Malakand Divisions. Therefore, the use of clean seed is important especially for the inhibition of the collar rot phase of the disease. Environmental factors such temperature and humidity as well as inoculum of the pathogen are positively correlated with disease. High temperature and humidity accelerate the pathogen to sporulate and also aid in spore germination and infection. These could have been responsible for high disease incidence in Peshawar than in Malakand Division (Adams and Stevenson 1990; Vloutoglou and Kalogeraki, 2000; Van der-Walls et al, 2001; Rotem 2004). Moreover, availability of inoculum round the year in alternative host as well as prevalence of the virulent isolates might also have been responsible for such results. Such observations are also supported by the work of Naik et al. (2010) who stated that the virulent isolates are faster in radial growth and high in disease rating.

In areas like Swabi, farmers usually relay on indiscriminate use of fungicides to combat the disease giving no consideration to the environmental conditions whatsoever which is not justified. This may also excesserbate consumer health issues by creating hazardous problems for both consumer and growers as well as to the environment. Such a practice may also be a cause of resistance build up in A.solani to the commonly used fungicides 
in Pakistan and elsewhere. Similar results have been reported from US in which stroblurin group of fungicides was no longer effective against early blight of tomato (Pasche et al. 2004). Meteorological factors such as temperature, duration of leaf wetness and moisture also have a great role in disease development (Adam and Stevenson, 1990; Vloutoglou and Kalogerakis 2000). It has been reported that increase in temperature accelerates sporulation (Vloutoglou and Kalogerakis 2000) while high humidity and rainfall promotes conidial germination of A.solani which leads to high infection (Vloutoglou and Kalogerakis 2000; Rotem 2004).

In general, the isolates collected from Peshawar and Mardan Divisions were more virulent than those collected from Malakand Division when tested both in vitro and in planta. Results are also in agreement with the previous work of Shahbazia et al. (2010) who reported variation in virulence among the isolates collected from different agro climatic zones. Among the isolates, the ones collected from Thoor Dehr and Shabqadar were more virulent in the screenhouse studies. The results are in agreement with other researchers (Tong Yunhui et al. 1994; Weir et al. 1998; Verma et al. 2006). Similarly Castro et al. (2000) demonstrated pathogenic variation among the isolates of $A$. solani. It was evident that isolates showing good growth were more virulent thus complementing each other. This is an agreement with the previous work of Naik et al. (2010) suggesting that isolate ASB2 was more virulent since it was faster in growth in vitro. Similarly, isolates also varied in their sporulation under in vitro condition whereby high number of spores $\mathrm{ml}^{-1}$ was observed in isolate collected from Shabqadar and lowest from Nasafa. Our data are in accordance with the earlier findings of Martinez et al. (1995) and Babu et al. (2000a) that isolates of A. solani varied in sporulation and type of growth as well as colony topology.

Table 4: Analysis of variance of radial growth of $A$. solani isolates

\begin{tabular}{llllll}
\hline Source & DF & SS & MS & F & P \\
\hline Isolates & 9 & 376.66 & 41.85 & 3.64 & 0.007 \\
Error & 20 & 230.00 & 11.50 & & \\
\hline Total & $\mathbf{2 9}$ & $\mathbf{6 0 6 . 6 7}$ & & & \\
\hline
\end{tabular}

$C V=12.41 \%$.
Table 5: Analysis of variance of number of spore $\mathrm{ml}^{-1}$ of $A$. solani isolates

\begin{tabular}{llllll}
\hline Source & DF & SS & MS & F & P \\
\hline Isolates & 9 & 565.36 & 62.8185 & 4.23 & 0.0035 \\
Error & 20 & 297.30 & 14.86 & & \\
Total & 29 & 862.70 & & & \\
\hline
\end{tabular}

$C V=15.48 \%$.

Table 6: Analysis of variance for virulence of $A$. solani isolates

\begin{tabular}{llllll}
\hline Source & DF & SS & MS & F & P \\
\hline Isolates & 9 & 357.518 & 40.60 & 2.77 & 0.027 \\
Error & 20 & 297.31 & 14.85 & & \\
Total & 29 & 658.39 & & & \\
\hline
\end{tabular}

$C V=16.86 \%$.

\section{CONCLUSION}

1. Higher incidence and severity of the diseases (early blight) was recorded in Peshawar and Mardanthan Malakand Division.

2. Isolates of $A$. solani collected from Peshawar and Mardan Division were more virulent than those collected from Malakand Division.

3. Segregation in population structure of the pathogen (A. solani) may be correlated to the variable environment prevalent in different regions of the province.

4. Prolong humid condition and non-rotation of soloconousr crop with cereal exacerbate the diseases in a specific location.

\section{REFERENCES}

Abada, K.A., Mostafa, S.H. and Hillal, M.R. 2008. Effect of some chemical salts on suppressing the infection by early blight disease of tomato. Egyptian Journal of Applied Science, 23(20): 47-58.

Abdel-Sayed, M.H.F. 2006. Pathological, physiological and molecular variations among isolates of Alternaria solani, the causal agent of tomato early blight disease Ph.D. Thesis, Fac. Agric., Cairo Univ., pp. 181.

Anonymous. 2012. Agricultural Statistics of Pakistan 20112012.Govt of Pakistan.

Adams, S.S. and Stevenson, W.R. 1990. Water management, disease development and potato production. American Potato Journal, 67: 3-11.

Babu, S., Seetharaman, K., Nandakumar, R. and Johnson, I. 2000a. Variability in cultural characteristics of tomato early blight pathogen. Plant Disease Research, 15: 121. 
Castro, M.E.A., Zambolim, L., Chavez, G.M., Cruz, C.D. and Matsuoka, K. 2000. Pathogenic variability of Alternaria solani, the causal agent of tomato early blight. Summa Phytopathologica, 26: 24-28.

Cerkauskas, R. 2005. Early blight. AVRDC, the world vegetable centre,

Chaerani, R., Smulders, M.J.M., vander Linden. B. Vosman, C.G. Stam, P. and Voorips, R.E. 2007. QTL identification for early blight resistance (Alternaria solani) in Solanum lycopersicum $\times$ S. Arcanum cross. Theoritical and Applied Genetics, 114: 439-450.

Chaerani, R. and Voorpis, R.E. 2006. Tomato early blight (Alternaria solani): the pathogen, genetics, and breeding for resistance. Indian Journal of Plant Pathology, 72(6): 335-347.

El-Abyad, M.S., El-Sayed, M.A., El-Shanshoury, A.R. and El-Abbagh, S.M. 1993. Towards the bio-control of fungal and bacterial diseases of tomato using antagonistic Streptomyces spp. Plant and Soil Science, 149(2): 185 - 195.

Fitt, B.D.L., McCartney, H. A. and Walklate, P. J. 1989. The role of rain in dispersal of pathogen inoculum. Annual Review of Phytopathology, 27: 241-270.

Ghosh, P.P., Mandal, D., Laha, S. and Dasgupta, M.K. 2009. Dynamic and severity model in management of fungal disease. Journal of Plant Protection Science, 1: 55-59.

Gomaa, A.M.I. 2001. Pathological studies on early blight of tomato. M.Sc. thesis., Fac. Agric., Cairo Univ.

Gwary, D.M. and Nahunnaro, H. 1998. Epiphytotics of early blight of tomatoes in Northeastern Nigeria. Crop Protection, 17: 619-624.

Harrison, M.D., Livingston, C. H. and Oshima, N. 1965. Control of early blight in Colorado. Fungicidal spray schedules in relation to the epidemiology of the disease. American Potato Journal, 42: 319-327.

Martinez, S.P., Snowdon, R. and Pons-Kuhnemann. 2004. Variability of Cuban and international populations of Alternaria solani from different hosts and localities: AFLP genetic analysis. European. Journal of Plant Pathology, 110: 399-409.

Mayee, C.D. and Datar, V.V. 1986. Phytopathometry Technical Bulletin-1. Marathwad Agricultural University, Parabhani, pp. 25.

McDonald, B.A. and Linde, C. 2002. The population genetics of plant pathogens and breeding strategies for durable resistance. Euphytica, 24: 163-180

Milgroom, M.G. and Peever, T.L. 2003. Population biology of plant pathogens. The synthesis of plant disease epidemiology and population genetics. Plant Diseases, 87: 608-617.

Momel, T.M. and Pemezny, K.L. 2006. Florida Plant Disease Management Guide: Tomato. Florida Cooperation Extensive Service, Institute of Food and Agriculture Sciences, Gaineville.

Naik, N.K., Prasad,Y., Bhat, K.V. and Devika, G.S. 2010. Morphological, physiological, pathogenic and molecular variability among isolates of Alternaria solani from tomato. Indian Phytopathology, 63(2): 168-173.
Pandey, K.K., Pandey, P.K., Kallo, G. and Banerjee, M.K. 2003. Resistance to early blight of tomato with respect to various parameters of disease epidemics. Journal of General Plant Pathology, 69: 364-371.

Patterson, C.L. 1991. Importance of chlamydospores as primary inoculum of Alternaria solani, incitant of collar rot and early blight on tomato. Plant Diseases, 75: 274-278.

Pelletier, J.R. and Fry, W.E. 1989. Characterization of resistance to early blight in three potato cultivars: incubation period, lesion expansion rate, and spore production. Phytopathology, 79: 511-517.

Pscheidt, J.W. 1985. Epidemiology and control of potato early blight, caused by Alternaria solani. Ph.D. Dissertation, University of Wisconsin-Madison.

Pelletier, J.R. 1988. Computer simulation of cultivar resistance and fungicide effects on epidemics of potato early blight. Ph.D. thesis, Cornell University, Ithaca, NY.

Pasche, J.S., Wharam, C.M. and Gudmestad, N.C. 2004. Shift in sensitivity of Alternaria solani in response to QoI Fungicides. American Phytopathological Society, 88: 2.

Rotem, J. and Reichert, I. 1964. Dew - a principal moisture factor enabling early blight epidemics in a semiarid region of Israel. Plant Diseases. Report, 48: 211-215.

Rotem, J. 2004. The genus Alternaria: biology, Epidemiology and Pathogenicity. American Phytopathological Society Press. St. Paul, MN, USA.

Shahbazi, H., Aminian, H., Sahebani, N. and Halteman, D.A. 2010. Biochemical evaluation of resistance response of potato to different isolates of Alternaria solani. Phytopathology, 100: 454-459.

Sherf, A.F. and MacNab, A.A. 1986. Vegetable Diseases and Their Control. John Wiley and Sons, New York.

Shtienberg, D., Blachinsky, D., Ben-Hador, G. and Dinoor, A. 1995. Effects of growing season and fungicide type on the development of Alternaria solani and on potato yield. Plant Diseases, 80: 994-998.

Simmons, E.G. 2007. Alternaria. An Identification Manual: CBS Biodiversity Series No. 6. CBS Fungal Biodiversity Centre, Utrecht, The Netherlands, pp. 775.

Shuman, J.L. 1995. Integrating a host resistance factor into a potato early blight-forecasting model. M.Sc. thesis, Pennsylvania State University, City.

Shtienberg, D. and Fry, W.E. 1990. Influence of host resistance and crop rotation on initial appearance of potato early blight. Plant Disease, 74: 849-852.

Tong-Yunhui, Liang-Jinong, Xu-Jingyou, Tong, Y.H., Liang, J.N. and Xu, J.Y. 1994. Study on the biology and pathogenicity of Alternaria solani on tomato. Journal of Jaingsu Agriculture College, 15: 29-31.

Taylor, J.H. 1987. Text of lectures delivered at the national workshop on fruit and vegetable seedlings production held at NIHORT 9-13.

Van der Waals, J.E., Korsten, L. and Slippers, B. 2004. Genetic diversity among Alternaria solani isolates from potatoes in South Africa. Plant Disease, 88: 959-964. 
Van der Waals, J.E., Korsten, L. and Aveling, T.A.S. 2001. A review of early blight of potato. African Plant Protection, 7: 1-12.

Verma, P.K., Singh, S. and Ghandi, S.K. 2006. Variability among the isolates of Alternaria solani associated with the early blight of tomato. Common Agriculture and Applied Biological Science, 71(4): 37-46.
Vloutoglou, I. and Kalogerakis, S.N. 2000. Effects of inoculum concentrations, wetness duration and plant age on development of early blight (Alternaria solani) and on shedding of leaves in tomato plants. Plant Pathology, 49: 339-345.

Wheeler R, B.E.J. 1969. An Introduction to Plant Diseases. John Wiley and Sons Limited, London, pp. 301. 
